\title{
Encroachment of Canals of Dhaka City, Bangladesh: An Investigative Approach
}

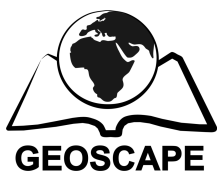

\author{
Asif Ishtiaque $^{1^{*}}-$ Mallik Sezan Mahmud ${ }^{2}$ \\ - Mahmudul Hasan Rafi ${ }^{1}$ \\ ${ }^{1}$ Department of Geography \& Environment, University of \\ Dhaka, Bangladesh. \\ *asif_ishti@yahoo.com \\ ${ }^{2}$ Department of Geography, University of Calgary, Canada.
}

\begin{abstract}
Dhaka City has been suffering from many environmental problems including flooding, water logging and other related problems. Urbanization, which is occurring very fast and with larger magnitude in Dhaka, is the intrinsic reason behind these problems. High rate of urbanization causes extensive urban area expansion and as a result canals, wetland and other water bodies are quickly vanishing from the landscape. This study shows the present physical condition of the canals; identifies the processes of canal encroachment; represents the consequences of canal encroachment. 13 canals of 50 were surveyed; local people were surveyed to identify the impact and processes of encroachment. According to this study, canals of Dhaka city are under serious threat of extinction and require immediate recovery actions. Canals are being encroached in various styles and this study identifies five: unauthorized land filling, illegal construction over canal, expansion of slum, solid waste dumping, taking advantage of lack of awareness of local people as well as government agencies. However, this study also discusses the grave consequences of canal encroachment: increasing flood vulnerability, wane of ground water recharge area and ground water level, collapse of natural drainage system, loss of local ecology and biodiversity.
\end{abstract}

Key words: Canals; Wetlands; Encroachment; Dhaka; Bangladesh

Received: 7 Oct 2014 - Accepted: 8 Dec 2014

\section{Introduction}

Dhaka, the capital of Bangladesh could be the best illustration of human activities and associated environmental change. Geographically Dhaka is located between $23^{\circ} 58^{\prime}$ and $23^{\circ} 90^{\prime}$ North latitudes and $90^{\circ} 33^{\prime}$ and $90^{\circ} 50^{\prime}$ East longitudes (see Figure 1). Topographically, the area is a flat land and is located mainly on an alluvial terrace, popularly known as the Modhupur terrace of the Pleistocene period (Miah 1968). Dhaka is surrounded by four major river systems, namely the Buriganga, Turag, Tongi and Balu, which are flowing to the south, west, north and east sides, respectively. The edges of the high lands are flanked by marshes and old river beds. The surface elevation of the area Dhaka are ranges between 1 and $14 \mathrm{~m}$ and most of the built up areas located at the elevations of 6-8 $m$ (FAP 1991). The surrounding rivers like the Buriganga, Turag, Tongi and Balu, are mainly fed by local rainfalls and also receive spills from three mighty rivers crisscrossing the country, namely the Ganges, Brahmamaputra and Meghna through their tributaries and distributaries in the monsoon (Taleb 2012).

Dhaka joined 'megacity' rank in 2001 with a population of 10.7 million (BBS 2003). Dhaka now holds 15.4 million populations in an area of 1530 square kilometers and becomes the world's 8th largest megacity (UN 2013). Between 1990 and 2005, the city doubled in size - from 6 to 12 million (Burkat 2008). Dhaka is the fastest growing megacity in the world, with an annual growth rate of 4.4 per cent per year (UN-HABITAT 
2008) (Figure 2). The rapid rise in urban population is a major drive to the development of infrastructure and services, including roadnetwork, water supply, sanitation, sewerage and drainage services and hence expansion of the city towards the surrounding floodplain and low-lying areas (Sultana 2009). Dewan and Yamaguchi found, in their study, that Dhaka expanded rapidly between 1960 and 2005, the amount of urban land increased from $11 \%$ (in 1960) to $34 \%$ (in 2005) (Dewan 2008). This urbanization is a demand driven unplanned and bottom up process, which transforming the existing landscape without considering the possible consequences and requirement for environmental sustainability (Brookfield 1988). These urban growths have profound adverse effect on the water resources, particularly in the humid tropical region (Sire 1991). In the tropical region where monsoon causes huge rainfall during some part of the year are naturally drains by the gravity drainage through stream-river networks, and wetlands works as natural retention storage (Sultana 2009).

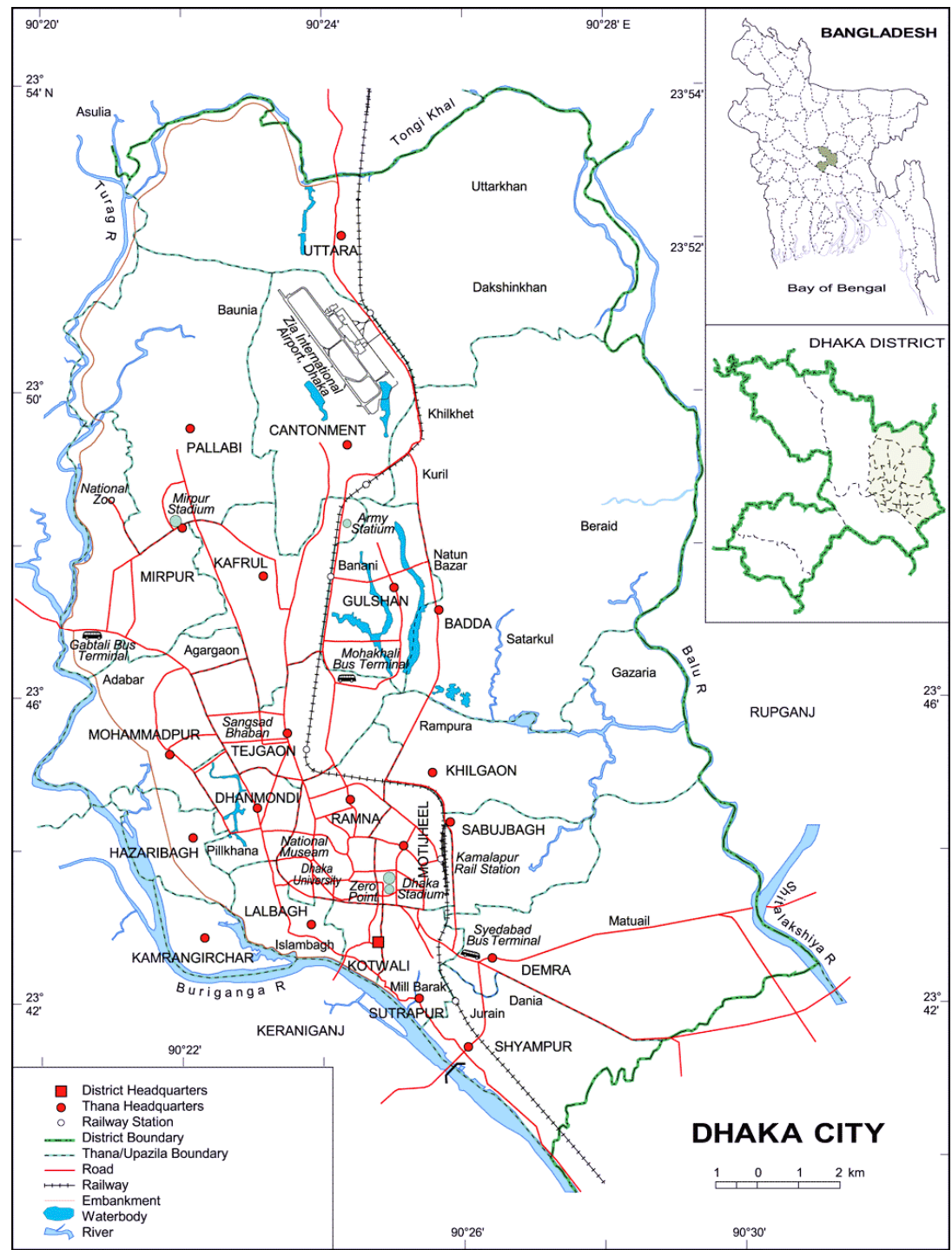

Fig. 1 - Location and basic topographic features of the Dhaka City. 


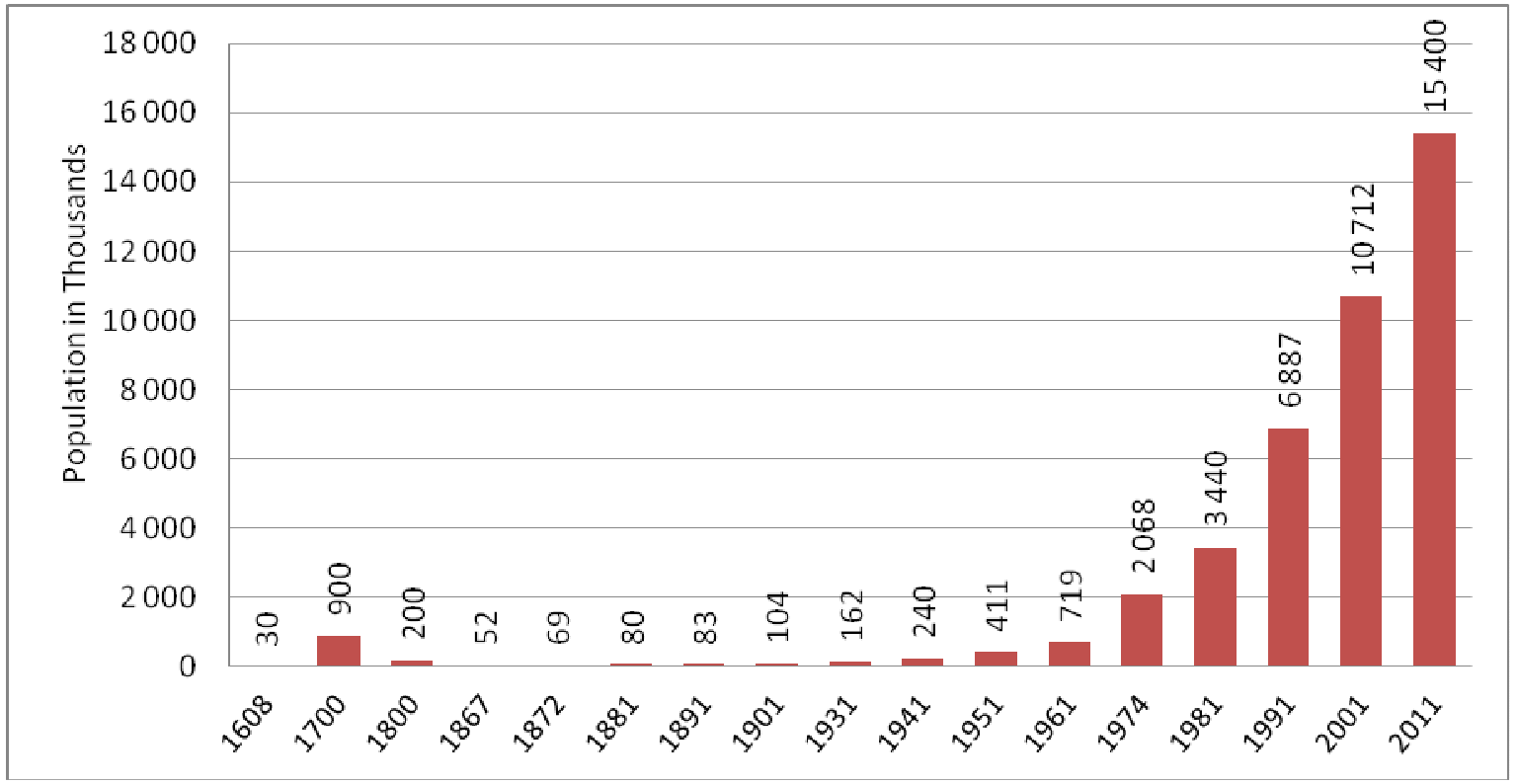

Fig. 2 - Population Growth in Dhaka Megacity (1608-2011). Source: BBS 1977; 1984; 1991; 1997; 2003; Taylor 1840; D’oyly 1824; Siddiqui 2000.

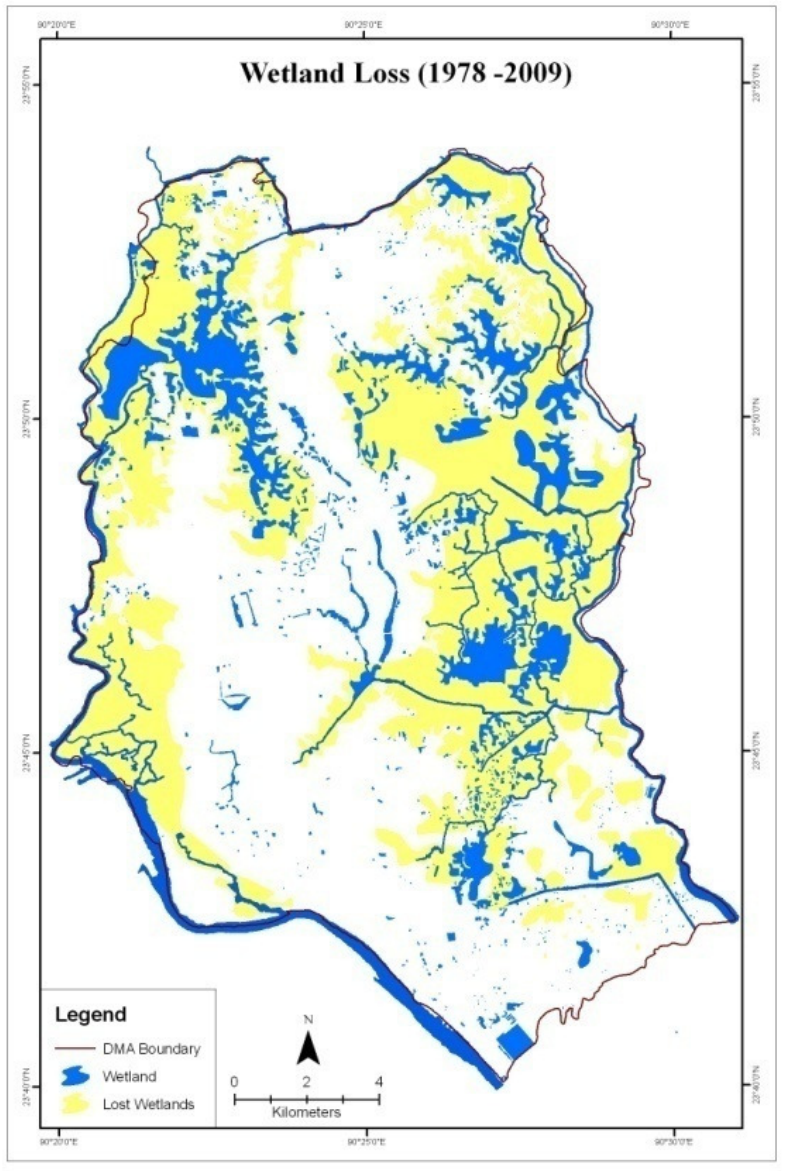

Fig. 3 - Wetland Loss (1978-2009). Source: Mahmud (2011). 
However, in Dhaka, the relief controlled landforms of the area were efficiently drained via streams and canals (local term 'khals') (JICA 1991) to the floodplain and low-lying area and ultimately to the downstream via large rivers. In the past the City was regarded as the Venice of the East or the City of Channels (Dani 1962). Even a few decades ago, there were numerous lowlands, canals and channels within and around Dhaka that would drain the City efficiently (JICA 1991). Canals of the city are used to be the connecting channels of the rivers surrounded by the greater Dhaka (Ahmed 1986). But now, these canals, wetlands and depressions have been filled up by new urbanization, both in and around the built-up city area (JICA 1991; Kamal 2004). These unplanned urbanizations have been destroying the water-bodies and flow-paths causing rainfallflooding and drainage congestion in many locations in the city (Kamal 2004; Chowdhury 2001; Reza 2002). Sultana (2009) found that in 1968, the total area of marshy and peaty inundated low-lying areas was $133 \mathrm{~km} 2$, which was depicted to be $67 \mathrm{~km} 2$ in the year 2001 (Sultana 2009). The total area of inland lakes as estimated from the aerial photos of 1968 was 5.1 $\mathrm{km} 2$ which became $1.8 \mathrm{~km} 2$ in the year 2001 as seen in SPOT image. Mahmud (2011) identified that about $60 \%$ of existing wetlands and about $65 \%$ of rivers \& canals are lost in last three decades in Dhaka Metropolitan Area (DMA) (Mahmud 2011) (Figure 3).

Filling activities, embankments and roads are being compartmentalized the wetlands and water bodies and hence obstructed the natural drainage. The city at the moment, particularly, during the heavy downfall in the wet-season gets water logged. The scenario would be worsening with time as erratic and intense rainfall events postulated (Islam 2009) to be increasing their frequencies due to climate change (Alam 2007). There is a general observation that the reduction of wetlands and other water bodies in Dhaka city is because of the progressive urbanization (Kamal 2004; Dewan 2006).

There were number of studies mentioned about the land filling activities and their effects on the drainage congestion and water logging (Kamal 2004; Chowdhury 2001b; Mark 2001). Moreover, several studies (Sultana 2009; Mahmud 2011; Reza 2002; Chowdhury 2001b; Mark 2001) have been conducted on the changes of the wetlands in the city. Chowdhury et al. (Chowdhury 2001a) pointed on the elimination of local water storage and consequences in the mid-central western part of Dhaka city while Reza and Alam (Reza 2002) showed the changes of wetlands in the western half of the city. Sultana (Sultana 2009) and Mahmud (Mahmud 2011) focused on the change analysis of wetland in Dhaka city. It was noticeable that, most of the studies emphasized mapping and discussing the impact of encroachment on the wetlands and drainage system of the city. In this study we have tried to identify how the encroachment happens; how does it affect the city environment; and in the effort of doing so we also tried to show the physical statuses of some canals of the city.

\section{Methods}

This study has been conducted in the month of February 2013. Both primary and secondary data have been used in this research. Out of 50 canals 13 canals have been selected in this study (Figure 4, Table 1). This selection was made based on the canal's geographical location and extent of catchment area. Only the canals, which have large catchment areas and which are situated in the peripheral zone of the city, have been selected, because these canals are responsible to flow water from the city to the rivers. To have an overview of the canals' statuses our team visited the canals physically and captured photographs. Furthermore a semi-structured questionnaire was designed to find out the process of canal encroachment and its associate impacts on city life. People living nearby the canals were considered as respondent. Moreover, an informal and open discussion was conducted with the authorities of Dhaka WASA. 


\section{Drainage Canals of Dhaka City}

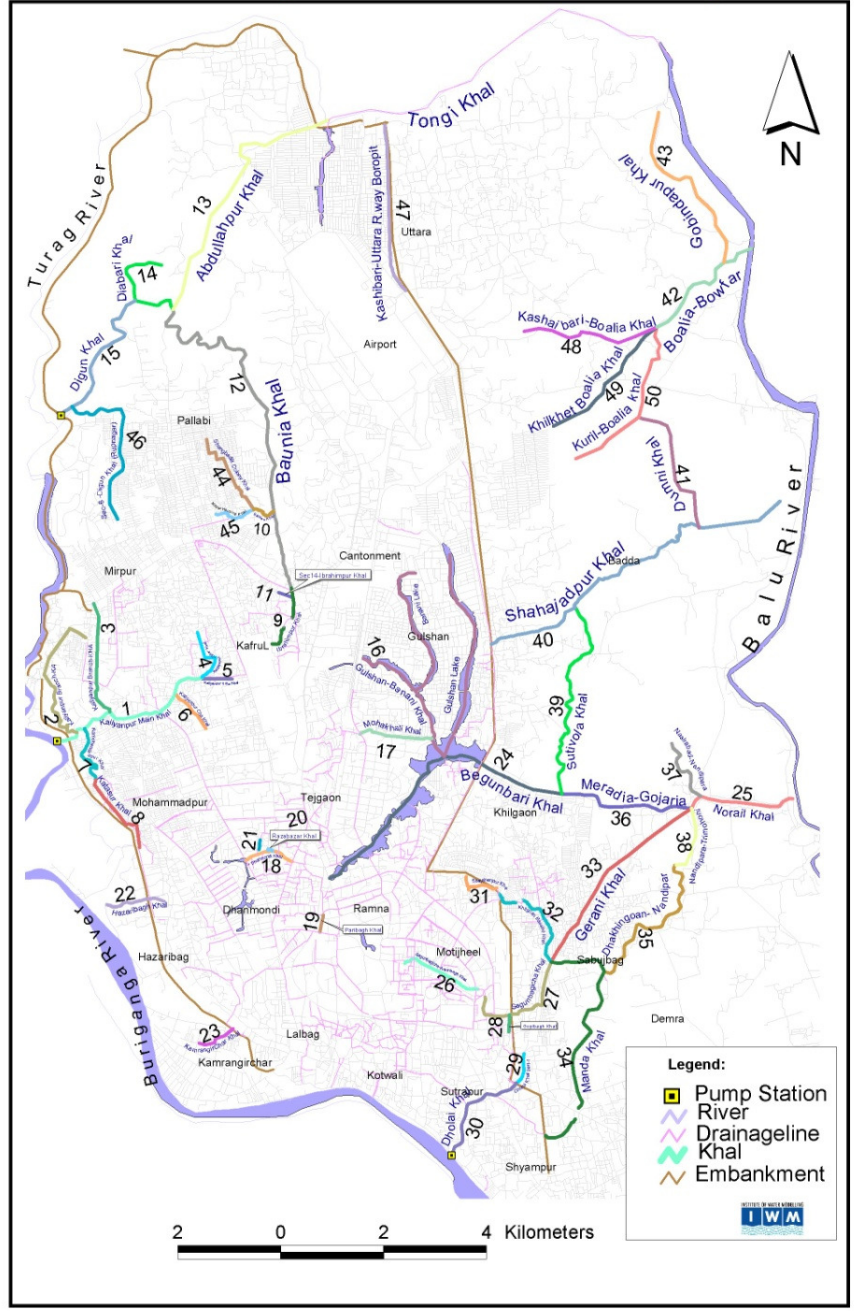

Fig. 4 - Drainage Canals of Dhaka City.

Table 4 - Studied Canals and its' Catchment Areas.

\begin{tabular}{lll} 
SL from Map & Name & Catchment Area \\
\hline 1 & Kalyanpur Main Khal & Kalyanpur, Adabor, Baitul Aman Housing \\
7 & Ramchandrapur Khal & Baitul Aman Housing, Mohammadpur \\
8 & Katasur Khal & PC Culture Housing, Mohammadpur \\
12 & Baunia Khal & Baunia, Mirpur Pallabi \\
13 & Abdullahpur Khal & Abdullahpur, Uttara, Baunia \\
15 & Digun Khal & Rupnagar, Eastern Housing Limited \\
27 & Segunbagicha Khal & Mugdapara, Maniknagar, Segunbagicha \\
32 & Khilgaon - Basabo Khal & Khilgaon, Basabo \\
33 & Gerani Khal & Gerani, Sabujbag, Khilgaon, Basabo, Mugdapara \\
34 & Manda Khal & Manda, Golapbag, Maniknagar, Green Model Town \\
40 & Shahjadpur Khal & Shahjadpur, Khilbari Tek, Nurerchala, Badda, Jauar Tek \\
46 & Mirpur 6 Digun Khal & Mirpur section 6, Rupnagar, Pallabi \\
48 & Koshaibari - Boalia Khal & Koshaibari, Boalia
\end{tabular}


The secondary information sources were various organizations such as Rajdhani Unnayan Kartripakhya (RAJUK), Bangladesh Water Development Board (BWDB), Disaster Management Bureau (DMB), Ministry of Water Resource, Bangladesh Bureau of Statistics (BBS), Institute of Water and Flood Management

(IWFM), Department of Water Resource Engineering (WRE) of Bangladesh University of Engineering and Technology (BUET) and Dept. of Geography and Environment of Dhaka University, Institute of Water Modeling (IWM).

\section{Canals in Dhaka City}

Although the total number of canals is contentious, Institute of Water Modeling (IWM) has identified that there exists 50 canals in Dhaka at present (Figure 4). The canals within the mega city Dhaka and the rivers surrounding the city were acting as natural drainage system, water reservoir, and the river route. However, this natural flow is severely hampered by human intervention, like land filling, waste dumping etc., and the present conditions of these canals become grim. In this study we have selected 13 canals, situated at the peripheral zone of the city, which are responsible for flowing out the city's water to the adjacent rivers. We have represented the present condition of those canals and then described the encroachment processes and its consequences.

\subsection{Kalyanpur Main Canal}

Kalyanpur canal is the drainage for whole Kalyanpur area as well as Adabor, Baitul Aman Housing and part of Shyamoli. A significant part of this canal is grabbed by slums households. Slum covers a wide area of Canal, having tin shed houses, built up on bamboo pillars. There is even a local vegetable market stands on the canal upon the pillars. It seems that the Canal is a popular dumping ground for the local people, who reside along the bank of the canal, and canal area is also used for the commercial buildings as well. Canal is getting shrunk due to garbage dumping and slum area expansion continues. It has been found that several mosques, residential and commercial buildings are situated in the encroached area. It appears that the canal is still being encroached by the land grabbers and DWASA's excavation activities are absent here. Around $40 \%$ of the canal is illegally grabbed.

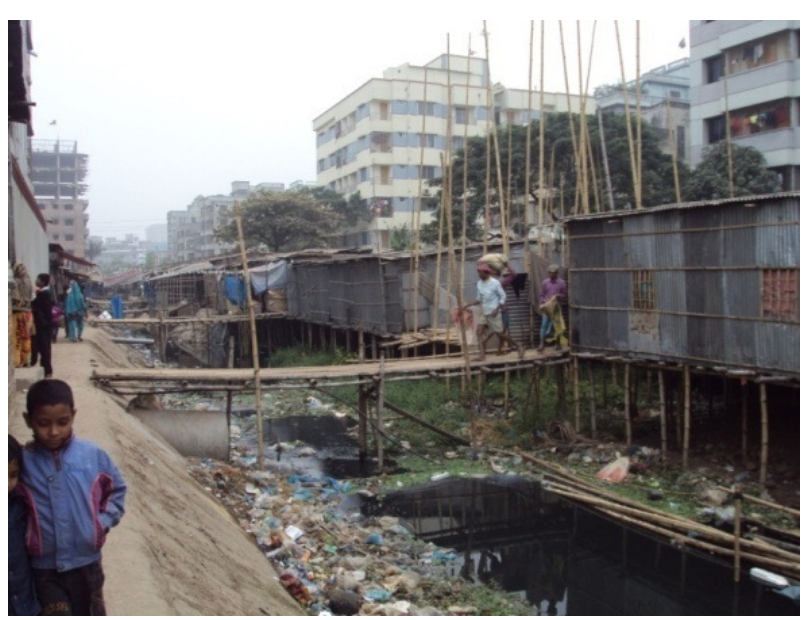

Fig. 5 - Illegal houses stand upon bamboo pillars.

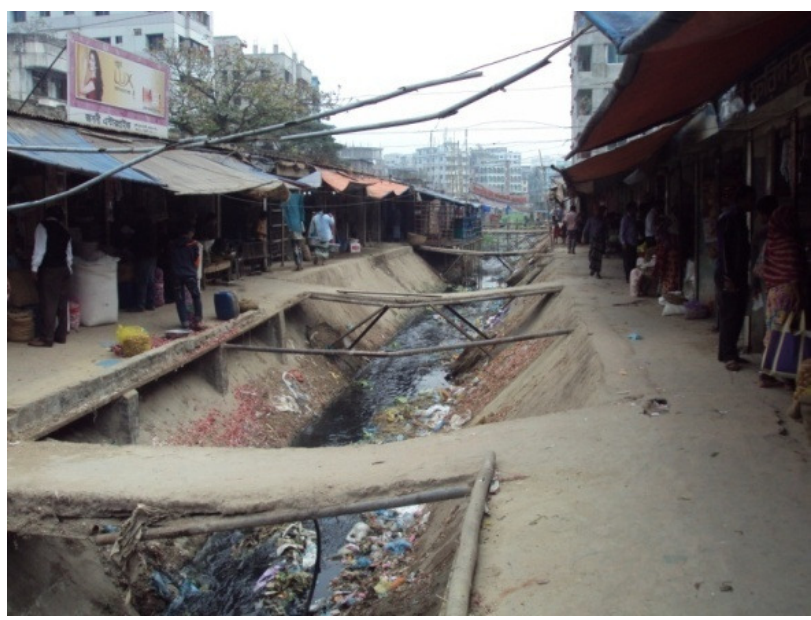

Fig. 6 - Local vegetable market throw waste into the canal.

\subsection{Ramchandrapur Canal}

Ramchandrapur canal is a regular garbage dumping ground for the local residents. In some places the water is stagnant due to accumulation of wastes. This stagnant water causes mosquito breeding. Moreover the canal waste includes non-degradable materials like polyethylene, which deteriorate the environmental condition. This canal creates bad odour condition in some points. Along with garbage dumping there are 
also illegal structures built by filling the canal. It appears that garbage dumping is a tricky method used to the canal, as an initial step to build an illegal house in canal's body. However, DWASA has done some excavation activities, though not in a very wide scale. These excavation activities are not currently on going. More than $50 \%$ of the canal is covered by wastes and illegal housing. It is strongly recommended to start a wide scale excavation action as soon as possible to protect this canal from dying.

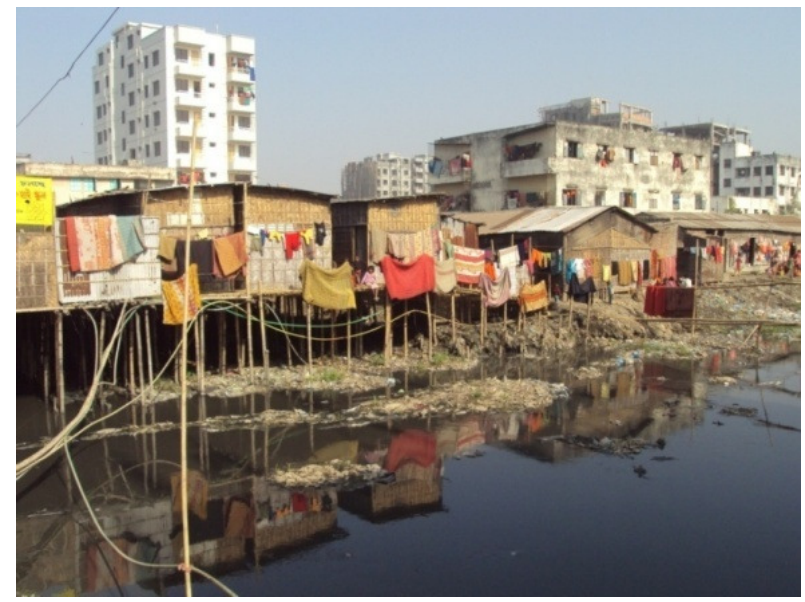

Fig. 7 - Illegal houses on the canal.

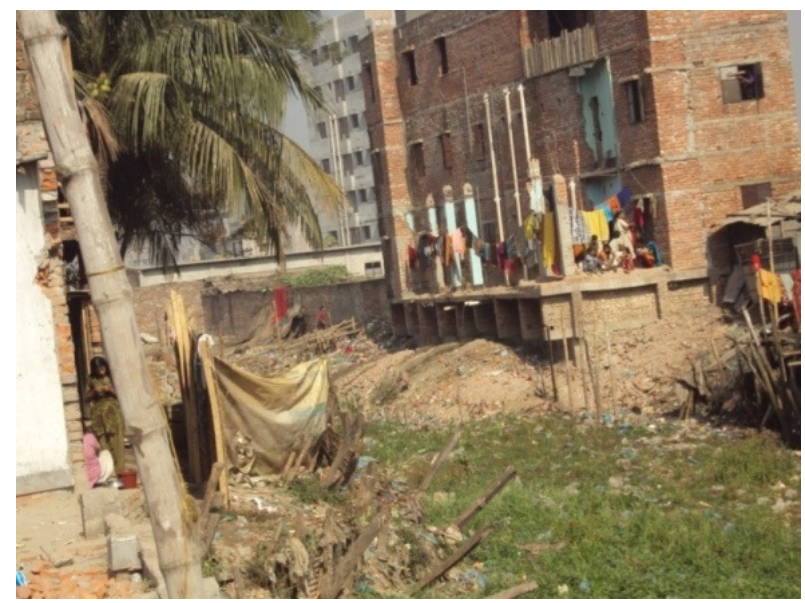

Fig. 8 - Illegal houses on the canal.

\subsection{Katasur Canal}

Katasur canal has dense population distribution along its banks. A number of box culverts are made on this canal, but most of these are poorly planned, as most of the culverts are very small in size and allow a narrow passage to pass water. As these culverts are small in size, roads have penetrated into the canal body along the two banks. These consequently hinder the natural flow of water. Garbage dumping in the canal is a serious problem in this canal. 'Land filling' can be considered as 'garbage filling'. The surrounding environment is polluted by foul odour. DWASA is constructing wide box culverts at some points without doing any kind of excavation work.

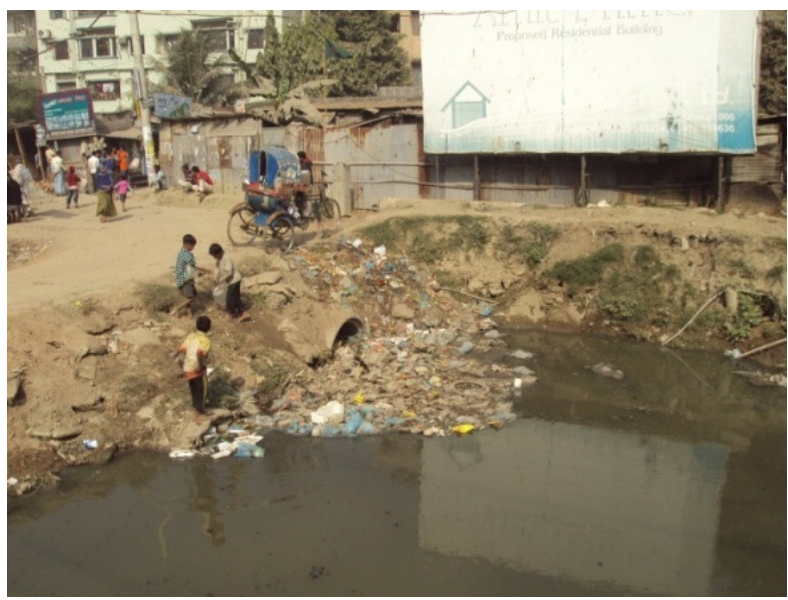

Fig. 9 - A narrow pipe beneath the road allows canal flow.

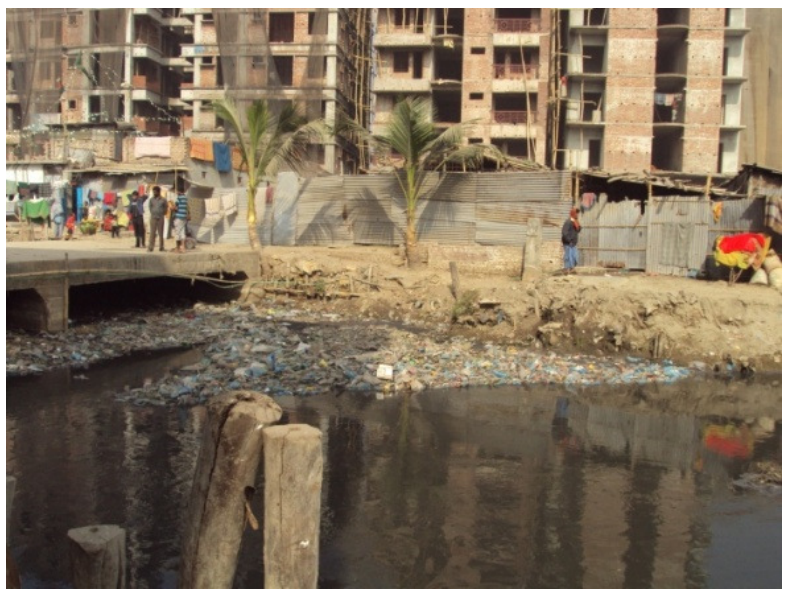

Fig. 10 - Waste dumping.

\subsection{Baunia Canal}

Baunia canal is in critical condition due to vigorous land filling. It has Mirpur area on the western bank and Uttara area in its eastern side. Both of these areas are extending by filling this canal. Land grabbing has become more intense 
after construction of a metal road along the embankment, which adjoins Uttara and Mirpur. This road has raised the commercial value of this area and it encourages the real estate companies to fill up the canal. However, garbage dumping is not very acute here. Although it is highly necessary to protect this canal, no excavation by DWASA is going on.

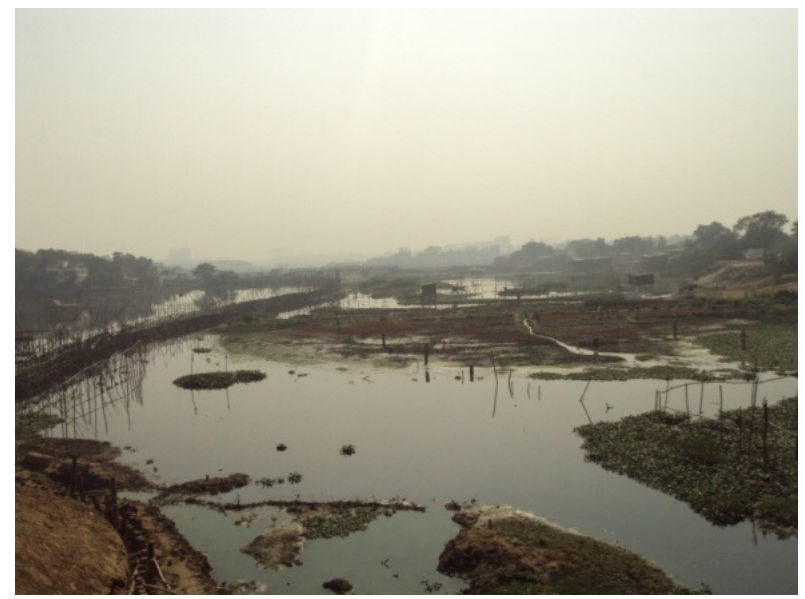

Fig. 11 - Vigorous land filling.

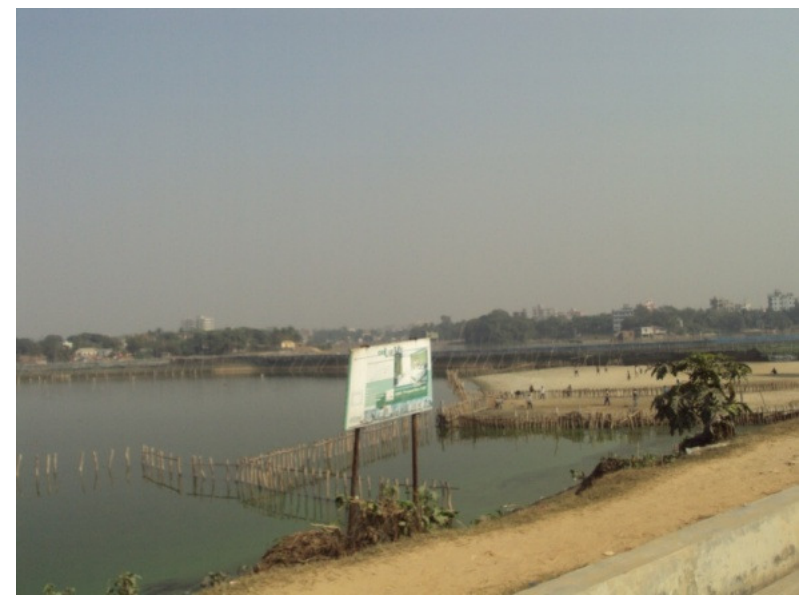

Fig. 12 - Real estate companies are filling the canal.

\subsection{Abdullahpur Canal}

Abdullahpur canal is a large canal flowing behind Uttara Model Town in the northern part of Dhaka. The government is constructing a road beside this canal and a bridge over it. However, DWASA is also active to excavate the canal bed, maintain and control the canal flow. At present this canal is obstructed at several points due to pisciculture. Local influential people are involved in this activity; they have made barriers in certain places and thus obstructed the natural flow of water. In the southern portion of the canal, there is evidence of vigorous land filling is found. As DWASA is working on improving this canal it is expected that this canal will not shrink by farther illegal land grabbing.

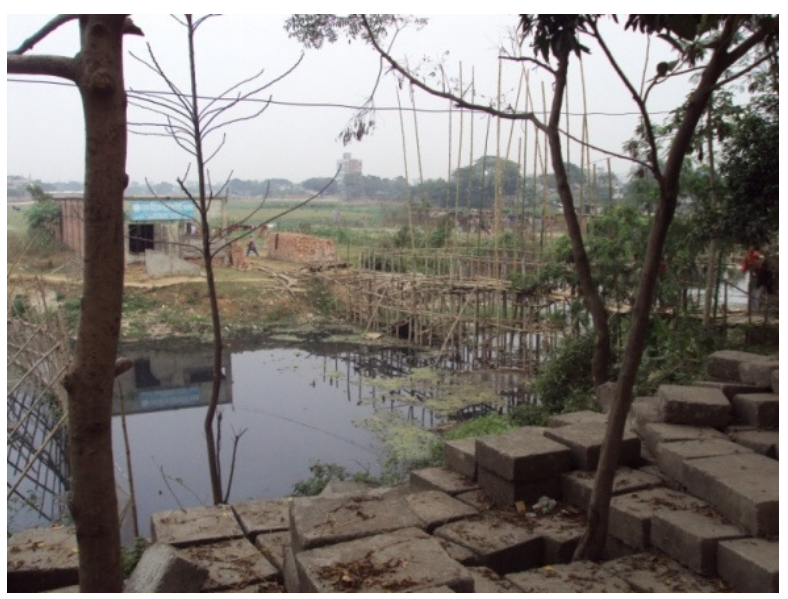

Fig. 13 - Illegal Bamboo Bridge on the Canal.

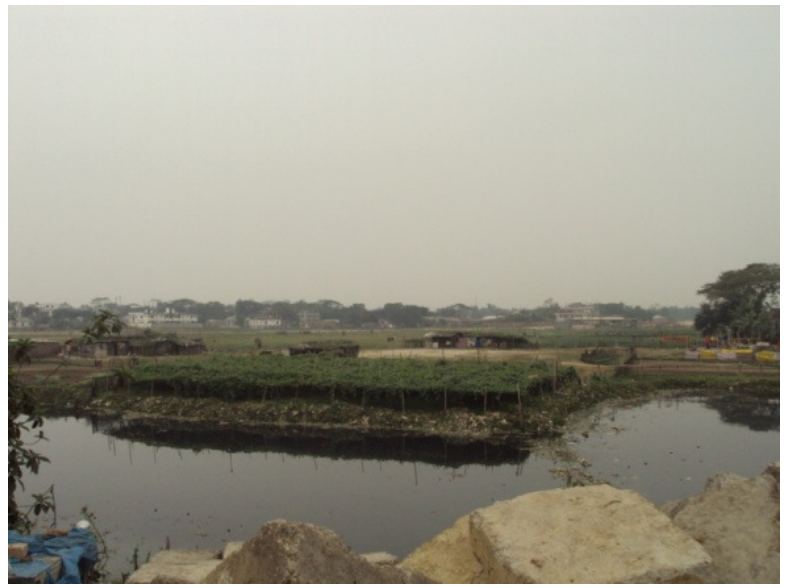

Fig. 14 - Cultivation in the canal filled land.

\subsection{Digun Canal}

Digun canal has marshy lands on its northern and western portions. Encroachment, in the way of development of new settlements, is going on, mainly from its south-eastern portion. The extended area of Rupnagar and Eastern Housing Limited is situated in this area. The environmental condition is now aggravated as some real estate companies have started to fill 
the canal's main course. It appears that this area is under great demand of real estate companies and some of them have claimed the canal area as their own property. DWASA is still inactive in this area and has not taken any excavation work and their ineffectiveness causes approximately $75 \%$ of the canal filled up. The bank of this canal is newly developed \& settlements are sparsely populated and for this reason garbage dumping in this canal is absent.

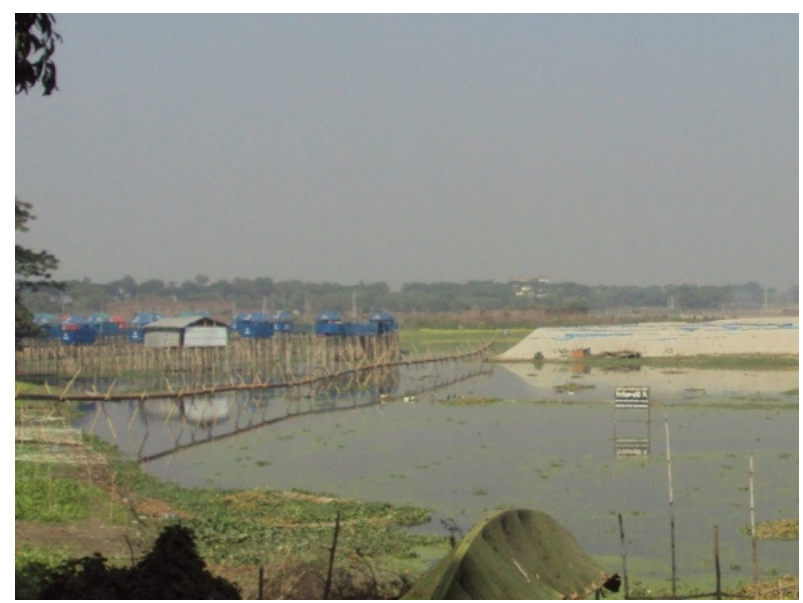

Fig. 15 - Land filling.

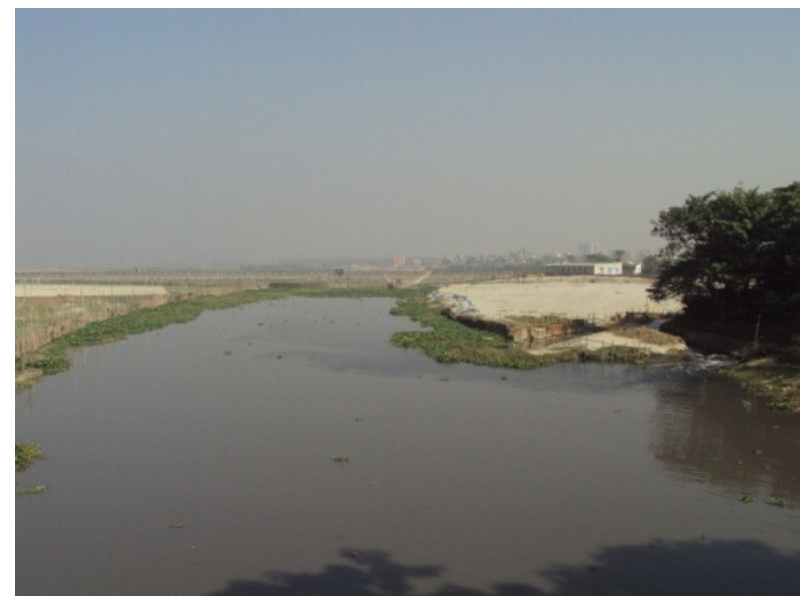

Fig. 16 - Land filling shrinks the canal.

\subsection{Segunbagicha Canal}

Segunbagicha canal is a narrow canal flows through densely populated Mugdapara and Maniknagar and Segunbagicha areas. This canal is in vulnerable condition and unfortunately DWASA has not done any excavation activities yet. This narrow canal is getting more narrowed down due to establishment of illegal houses and continuing garbage dumping by local people. Most of the buildings situated along the bank of the canal encroach the canal's area. These aggression blocks about $60 \%$ of the canal flow. An immediate step to clean this canal is urgent. At one place along the bank the canal has a paved side road, which prevents the illegal use of the canal area. It represents that paved banks can prevent grabbing or encroachment of canals.

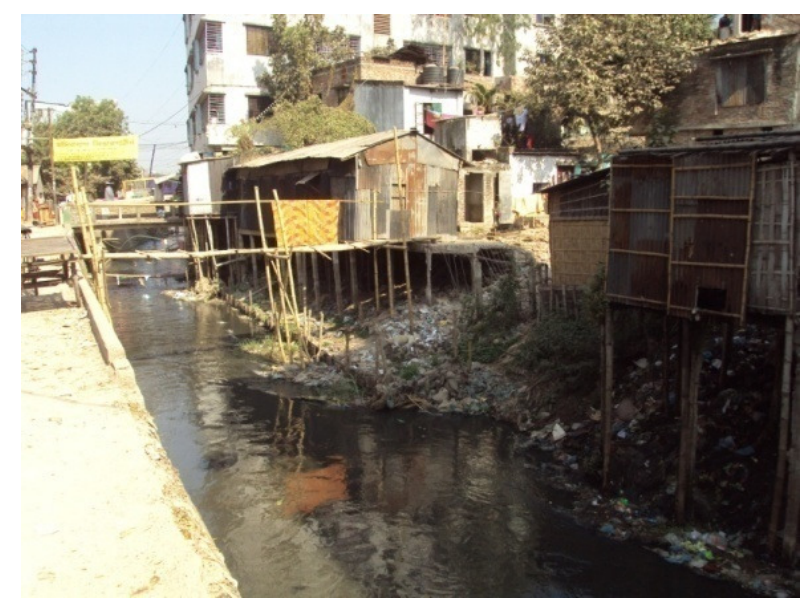

Fig. 17 - Illegal houses on the canal.

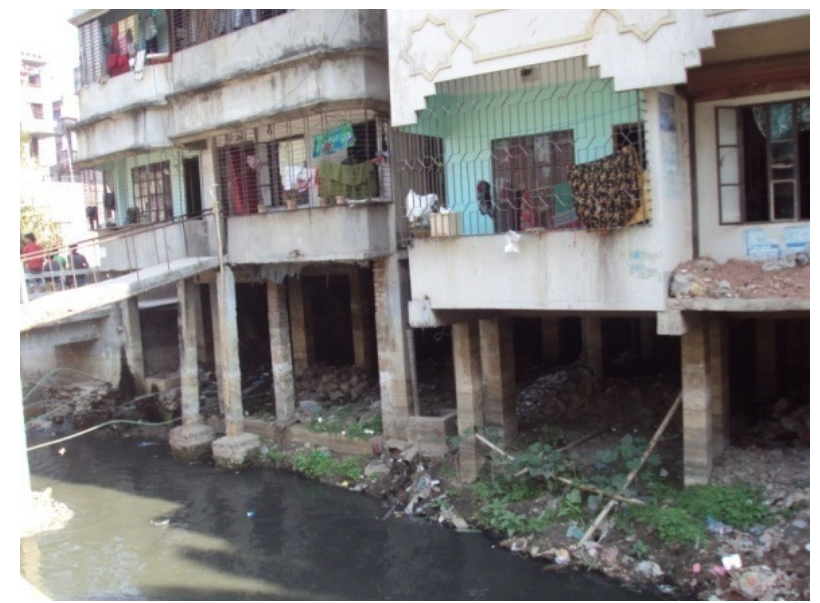

Fig. 18 - Illegal structures on the canal.

\subsection{Khilgaon-Basabo Canal}

This small canal flows through the Khilgaon and Basabo areas and joins the Manda canal. DWASA is actively working on this canal, and making a pavement along the canal. As this canal flows 
through residential areas, a lot of garbage dumping is found here. However, DWASA is developing the canal in a planned way. Like Dhanmondi canal, DWASA has a plan to develop same box culvert over this canal and allow roads as well as maintain the water flow.

\subsection{Gerani Canal}

Gerani canal has the catchment area of Gerani, Sabujbag, Khilgaon, Basabo, Mugdapara and these places are densely populated. Like other canals in densely populated area, Gerani canal also faces uncontrolled waste dumping and unlawful encroachment. This canal becomes a breeding ground of mosquitoes and emit foul odor in the adjacent areas. DWASA is supposed to responbsible for maintaining this canal, but, it is apparent that they fail to do so.

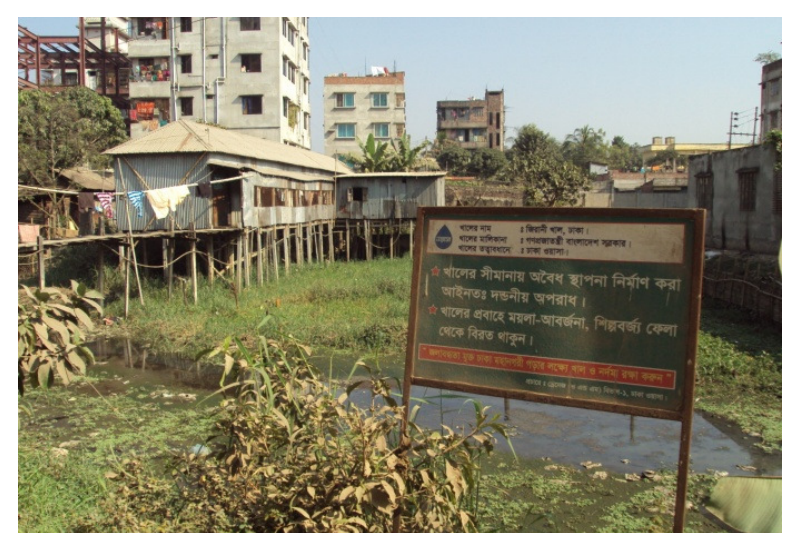

Fig. 19 - Illegal houses on the canal just behind the awareness signboard of DWASA.

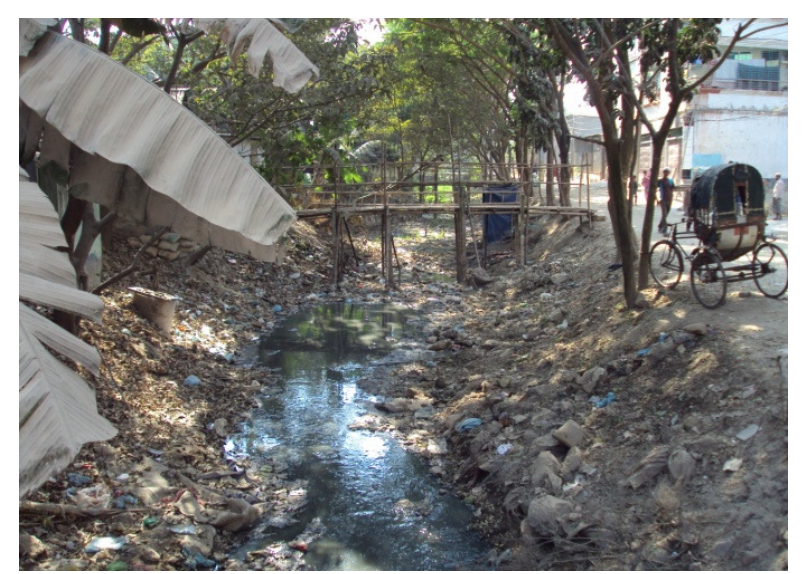

Fig. 20 - Waste in the canal.

\subsection{Manda Canal}

Manda canal is situated at the south-western edge of Dhaka city. In this canal at present DWASA is not active. A housing project named Green Model Town has been built along its bank. Construction of houses, built on pillars encroach the canal area and is a very common practice in the area. Land filling is also a dominant activity and it is found that often agricultural activities are being done in these filled lands. A very strange thing found here is that there are some houses which are built upon pillars in the middle of the canal. These houses have no land based connection. Boat is the only medium of transportation. The northern portion of the canal has scattered isolated settlements. Although land filling is dominant but till now only about $20 \%$ of this canal is affected by these activities.

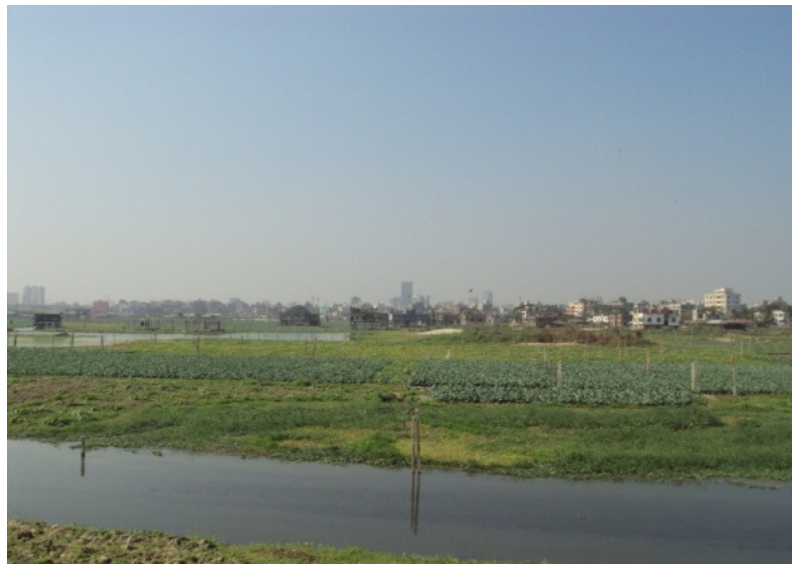

Fig. 21 - Bamboo pillars for land filling.

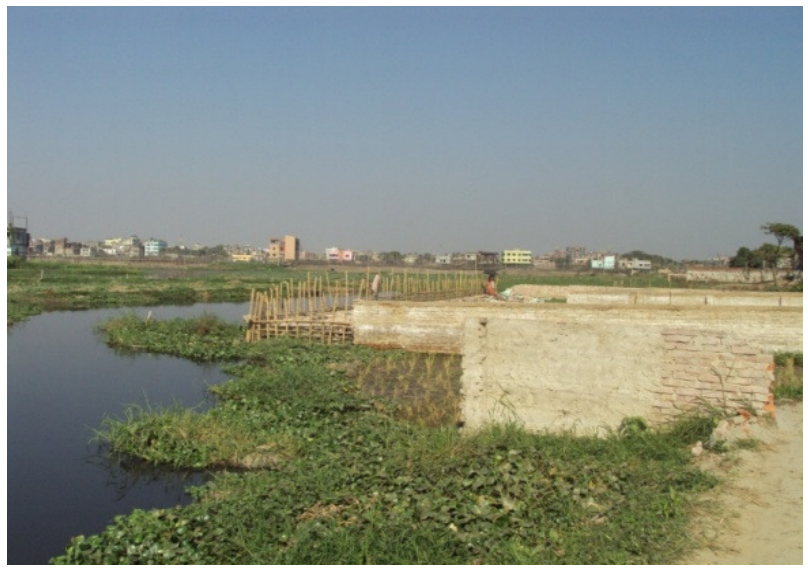

Fig. 22 - Illegal structures in canal's area. 


\subsection{Shahjadpur Canal}

Shahjadpur canal flows through Badda to Jauar Tek and falls into Dumni canal at the very eastern side of the city. At the initial stage of the canal dense population surrounds it in both sides of its banks. This canal look like a large drain flowing through the narrow spaces of buildings near its starting point. It is also critical condition due to huge amount of garbage dumping.

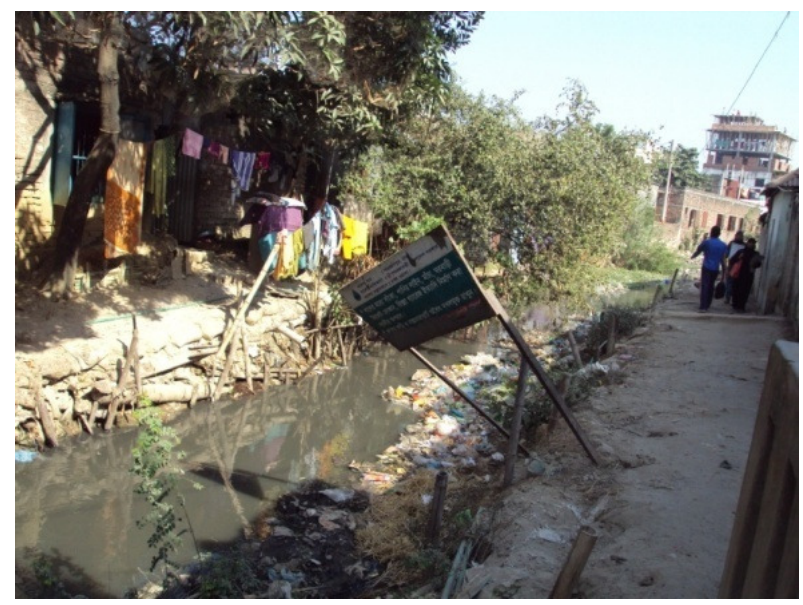

Fig. 23 - DWASA's awareness signboard is hanging due to vigorous encroachment.

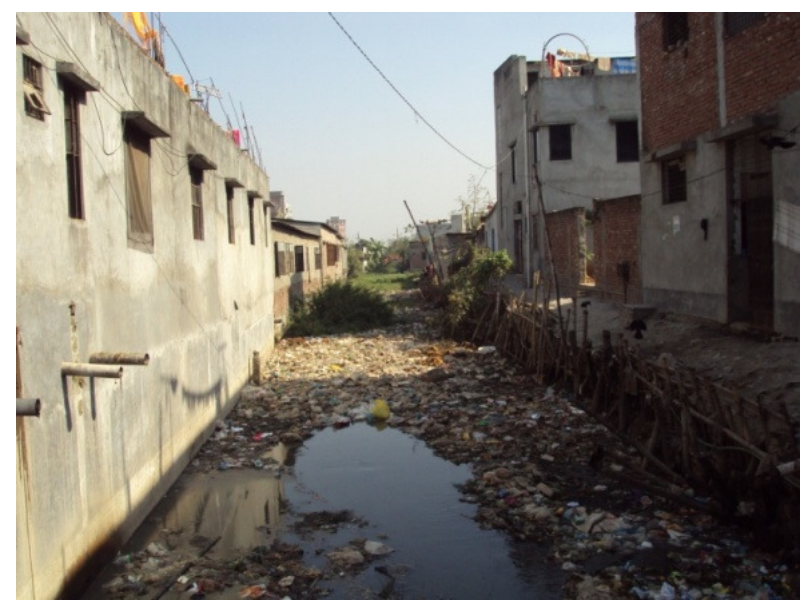

Fig. 24 - Houses along the bank of the canal violates canal's delineated area.

Severe encroachment has occurred along this canal. Garbage dumping is so heavy here that it has obstructed the natural flow of water totally. In this stage the canal flows through densely populated Shahjadpur and Khilbari Tek areas. At some point, land encroachment is going on without any interference from the authority. Eastern side of the canal is surrounded by marshy lands and is very sparsely populated. Vigorous land filling is going on, especially in Jauar Tek areas.

\subsection{Mirpur 6 Digun Canal}

Mirpur 6 Digun canal flows through the Mirpur section 6 and Rupnagar area. This canal is at present under the development project of DWASA. DWASA is active in improving this canal. They are constructing a canal side road by demolishing some illegal establishments. Recently, they demolished about 500 illegal structures along about 3.5 kilometers of the canal's area at Pallabi. As the bank of the canal is not densely populated, garbage dumping is not very prominent, though at some specific point garbage dumping is severe. Towards the end of the canal, where it joins with Digun canal, the canal is seriously obstructed by housing projects, which are causing land filling. Illegal households are encroaching the canal. The land filling by a housing project is causing severe damage and has changed the course of the canal. DWASA excavated some areas of the canal's bank about a year back. The end point of this canal is very badly encroached but unfortunately DWASA has not conducted any cleaning in this point.

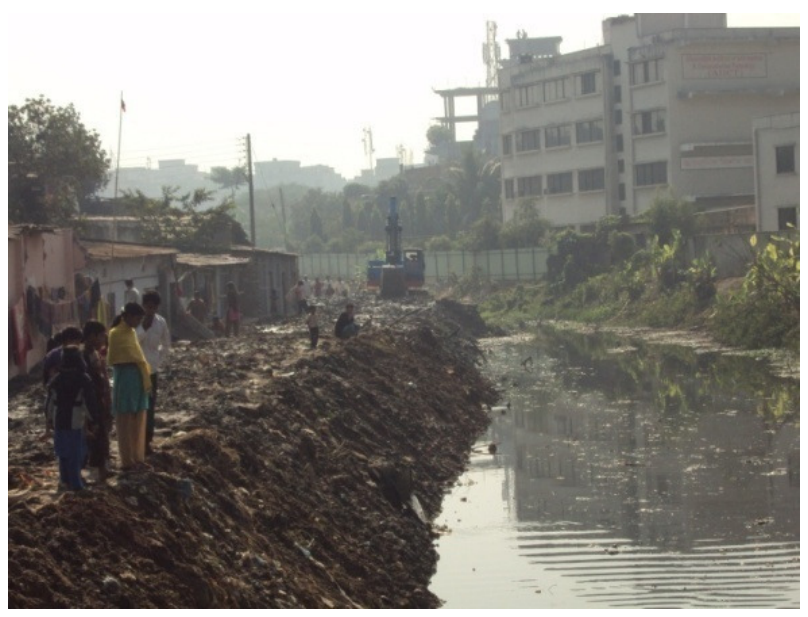

Fig. 25 - Construction of canal side road. 


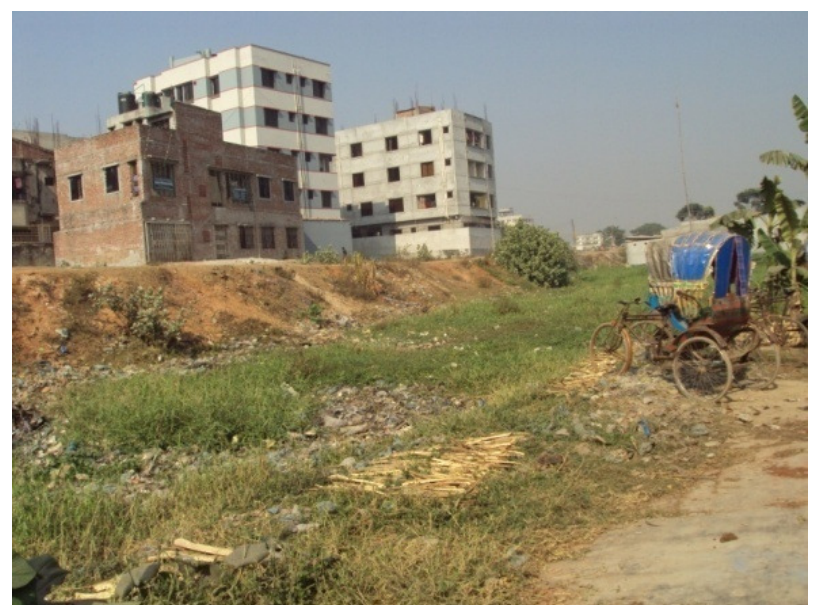

Fig. 26 - Stagnant water emits foul odour.

\subsection{Koshaibari - Boalia Canal}

Koshaibari-Boalia canal flows through Koshaibari and Boalia area and falls in the Boalia canal in the eastern edge of Dhaka city. This canal is locally known as a 'drain' because of its small size. In Koshaibari the area of identification of the canal is tough. This is because of extensive encroachment and land filling. Like the Gerani canal this canal is also a victim of land filling. The canal water flows very slow and in some places, aquatic plants have grown making the canal marshy land. The canal has seen filled up in an unauthorized way, obstructing the natural flow of water. Almost $80 \%$ of the canal is grabbed by local people.

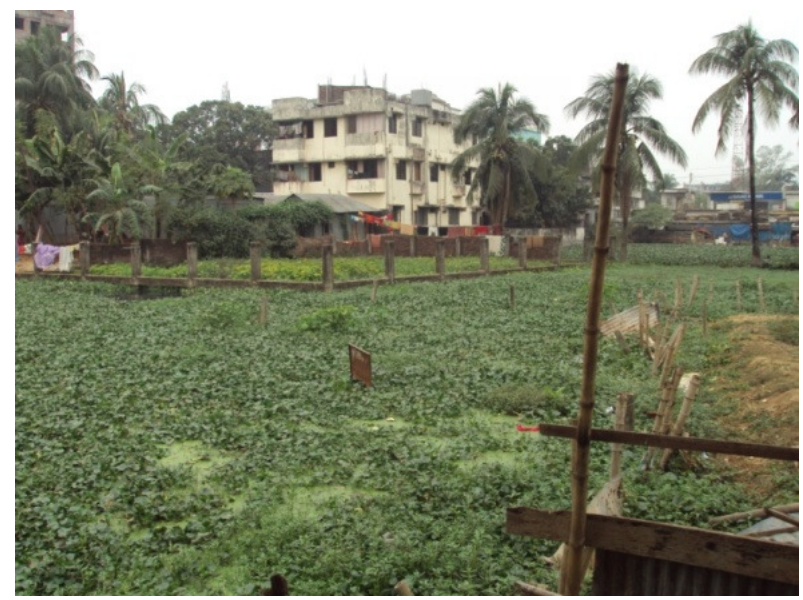

Fig. 27 - Stagnant water causes the growth of aquatic plants.

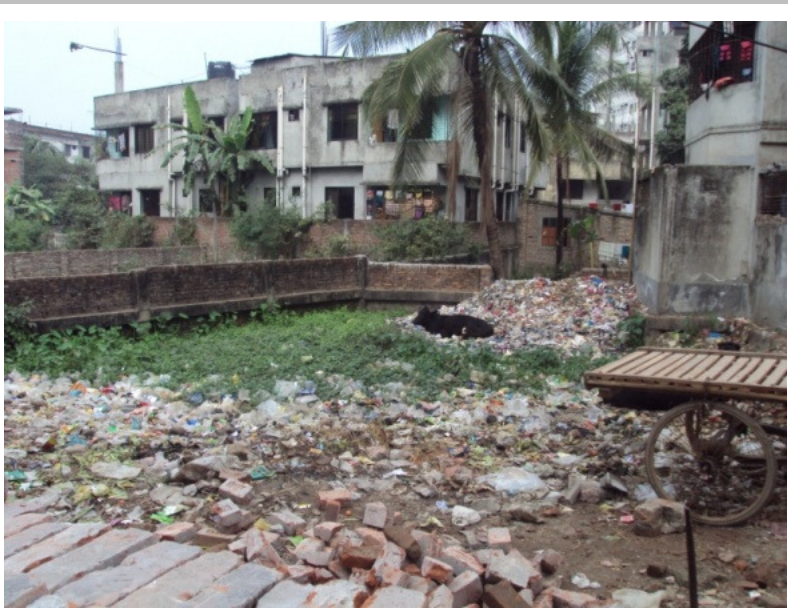

Fig. 28 - Vigorous waste dumping and illegal structure obstruct the canal flow.

\section{How the encroachment occurs?}

The questionnaire survey revealed several factors responsible in the encroachment process of the canal.

\subsection{Unauthorized Land Filling}

Filling in a wetland occurs when earthen or other miscellaneous material is used to fill in the area of a wetland and to raise the final elevation of the site. History of urban growth in Dhaka demonstrates that the city is being expanding to the eastern part, low-lying areas, in the recent decades. These urban expansions are mostly occurring on to the wetlands in the eastern part, which were suggested to act as retention basin for urban drained water. The peripheral zone of Dhaka city is vigorously filled up by real estate companies. These companies often are encroaching canals in such a way that it prohibits the natural outflow of water during monsoon and thus create water logging. In primary phase these companies flout laws and claim the canal's area as their own by putting bamboo sticks in the canal and they gradually fill-up low-lying areas by carrying sand/earth from other areas using country boats and engine boats. 


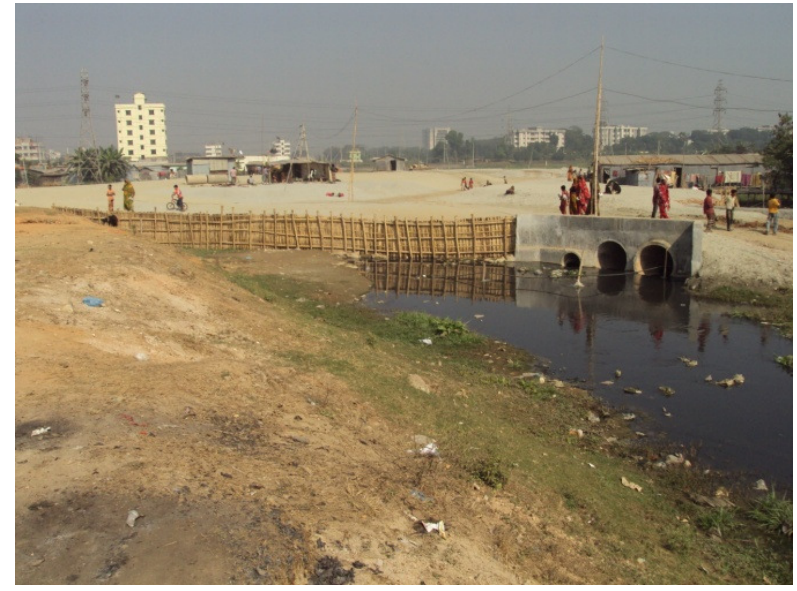

Fig. 29 - Canal Encroachment by Real Estate Companies (A).

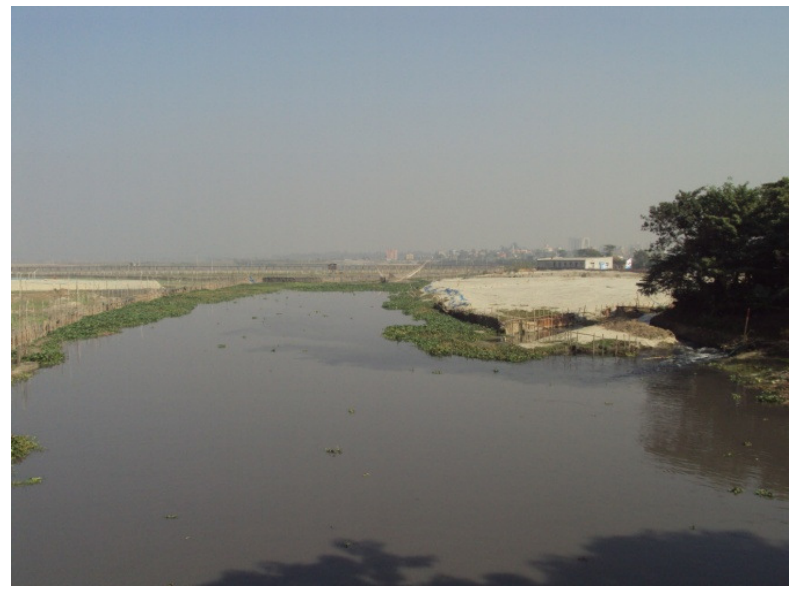

Fig. 30 - Canal Encroachment by Real Estate Companies (B).

\subsection{Illegal Construction over Canal}

Another major process of encroachment is building houses over the canal. These buildings are built on pillars and the entrance way is created by canal filling. Sometimes to encroach, bamboo posts are positioned and fixed on the water body bed along the bank and extending into the main body of the wetland. Then huts and shops are built on these stilts. The owners of these structures are then start reclaiming land by earth fills and dumping garbage. Aside from this style, some influential people use religious institution for encroaching. In several canals of Dhaka city, we have found that, the preliminary stage of encroachment is through establishing a mosque in the canal. No government agency can move that mosque because of its religious significance. By providing the excuse of building road to that mosque the local influential people start to encroach the canal.

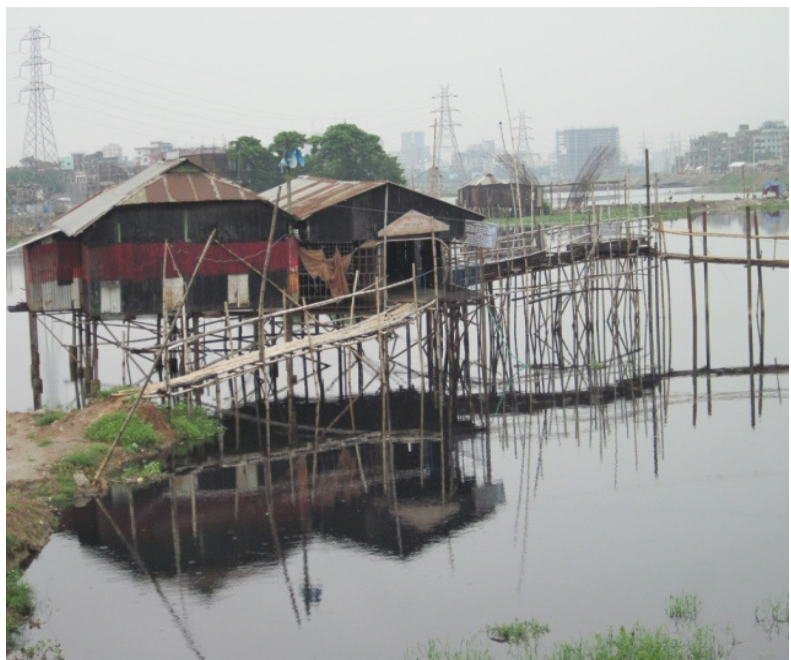

Fig. 31 - Encroachment by Mosque and Illegal Buildings (A).

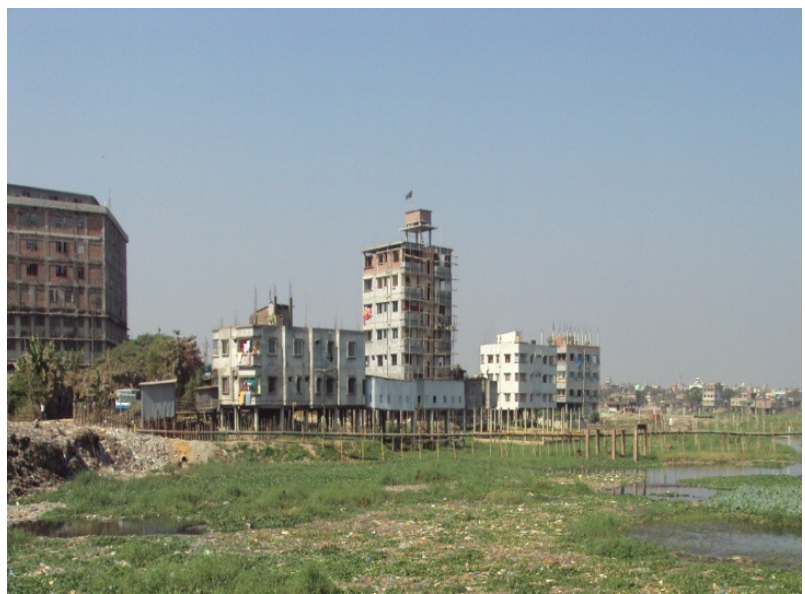

Fig. 32 - Encroachment by Mosque and Illegal Buildings (B).

\subsection{Expansion of Slum}

Because of the high rate of urban growth and rapid rural urban migration, Dhaka city experiences development of slums. At present Dhaka Megacity contains 4966 slums in its 1530 $\mathrm{km} 2$. These slums are generally built up in urban outskirt and also over wetlands. In Dhaka more than $37 \%$ of the total city population lives in 
slums and the slum population density is 220,246 persons per $\mathrm{km} 2$. Slums are controlled by local political leaders and they often expand the areal extension by building new houses over the canals on pillars and then rent it to poor people.

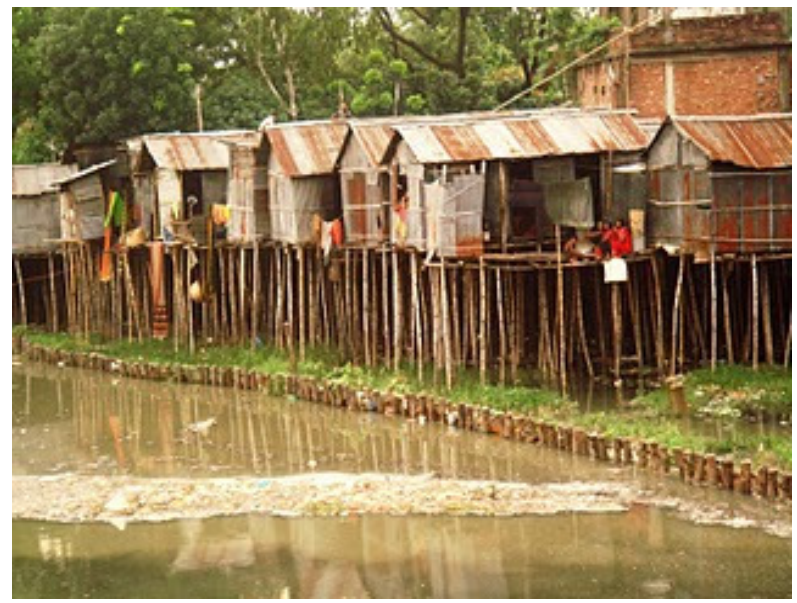

Fig. 33 - Slum Expansion in Gulshan Canal and Ramchandrapur Canal (A).

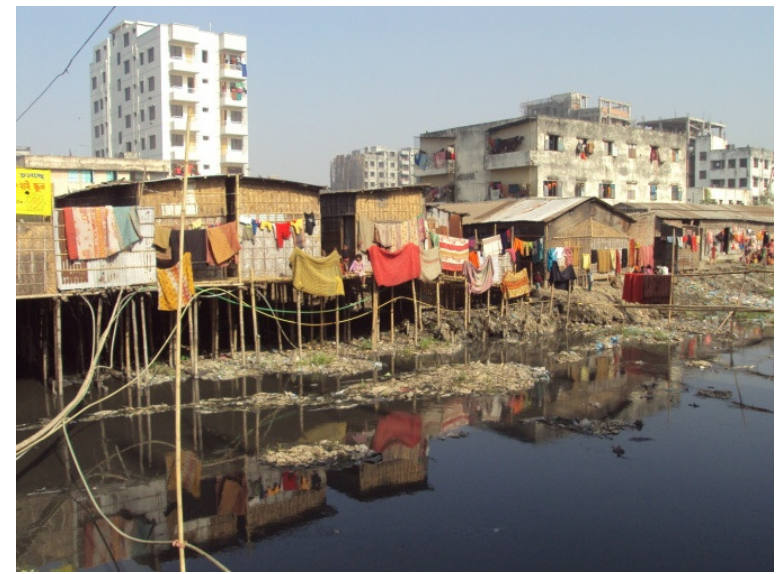

Fig. 34 - Slum Expansion in Gulshan Canal and Ramchandrapur Canal (B).

\subsection{Solid Waste Dumping}

Solid waste dumping in the canal is one of the most common processes of encroachment. Often canals become dumping grounds for domestic and industrial wastes and breeding grounds for mosquitoes. Dhaka city does not have an integrated solid waste management system and for this reason both solid and liquid waste is dumped in the canals. Most often the waste is visible on the streets, canals side and in the drains. There is almost no sanitary landfill or any other facilities like incineration. About 400 tons out of average 3,500 tons of solid waste, generated in the city every day, remains on the roads, open spaces and in canals. These solid wastes are at times so enormous in amount that the canal water flow fails to carry them away and consequently causes water congestion. Thus dumping of solid waste becomes a process of encroachment.

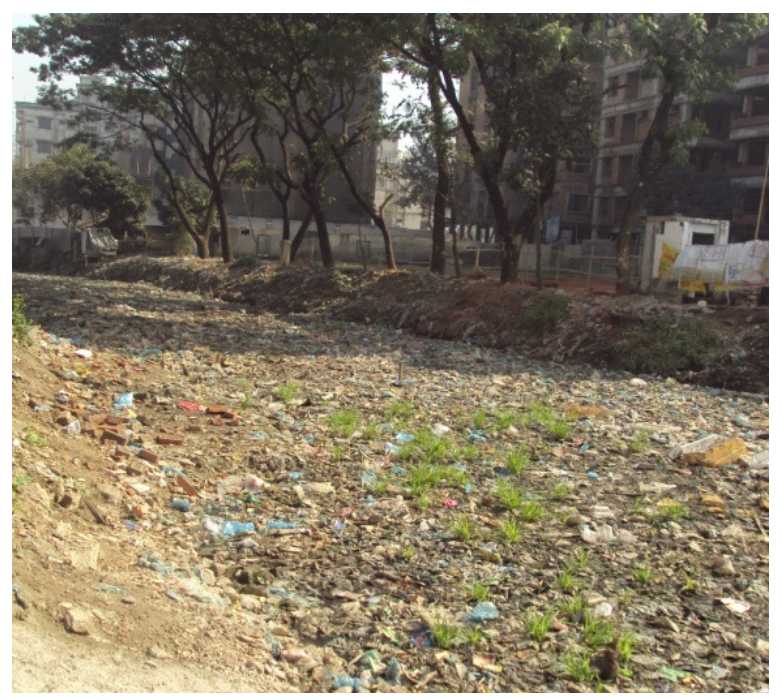

Fig. 35 - Solid Waste Dumping in Katasur and Kalyanpur Canal (A).

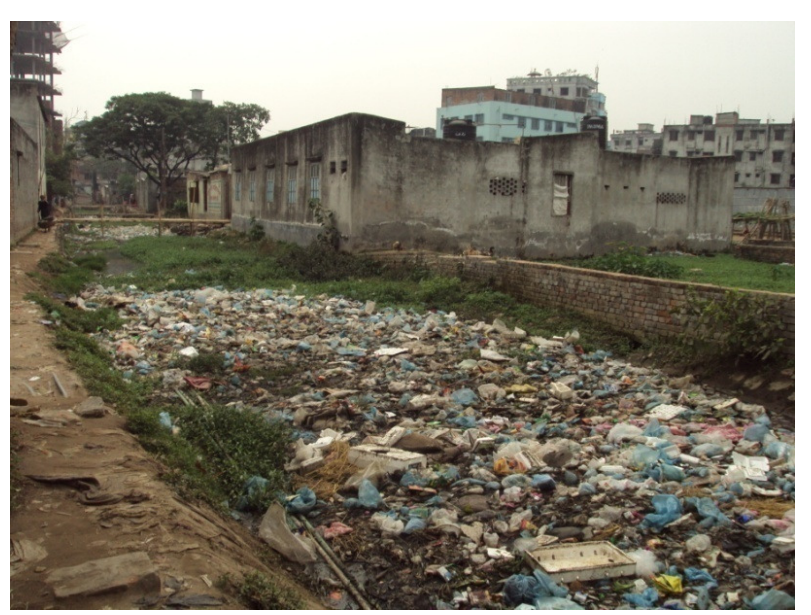

Fig. 36 - Solid Waste Dumping in Katasur and Kalyanpur Canal (B). 
4.5 Taking Advantage of Lack of Awareness of Local People and Govt. Agencies

Lack of awareness of both governmental agencies and people abet this encroachment process. Real estate companies continue filling up land because of RAJUK's ignorance and corruption. In some cases RAJUK itself is involved in unplanned wetland filling. DWASA is also responsible for maintaining uninterrupted water flow but, however, due to lack of manpower, infrastructure, they fail to protect these canals from encroachment. Moreover, general people, who live beside canal, are often not very much aware of the consequence of throwing waste into the canals or blocking the natural water flow by building up houses over it. As a result, it has been found that local people are responsible for encroachment or water congestion.

\section{Consequences of encroachment}

\subsection{Increasing Flood Vulnerability}

Wetlands of Dhaka metro area perform a significant role to reduce impact of flood (JICA 1992; Dewan 2006). Within the embankment area, these flood plain wetlands act as storm water retention areas. Outside the embankment they are active flood plains of adjacent rivers. Bangladesh atomic energy commission and SWMC (Bangladesh Atomic Energy Commission and SWMC, 2002) carried out a study on Ashulia flood plain area to find the impact of land filling activity on the surrounding hydrology. Findings of the research states that; the land development will increase the water level of the river, which may cause drainage problem in the areas and flow velocity of the river will also increase. On the other hand, vigorous land filling will prevent the water to flow out naturally. Consequently, water will be logged in the city and thus create flooding.

\subsection{Wane of Ground Water Recharge Area and} Ground Water Level

According to a study conducted by SWMC (2000), about $95 \%$ of water supplied for Dhaka is extracted from underground and average annual decline of ground water within the city area during 1995 to 1999 varied from $1.02 \mathrm{~m}$ to 2.46 $m$ (WASA 1991). Canals and low land play significant role in ground water recharge function.

\subsection{Collapse of Natural Drainage System}

Canals have dominant role in drainage function. Storm runoff from the surrounding areas is stored in the lowland areas (Chowdhury 2001b). The accumulated run-off is gradually drained to the peripheral rivers through drainage canals (Chowdhury 2001a). Drainage system of Dhaka city consists of forty three major canals. These canals used to drain out the waste water (domestic and sewerage) and storm runoff to the surrounding rivers. Heavy encroachment processes in the outskirt canals is causing the inevitable collapse of natural drainage system.

Disturbance of Local Ecology and Biodiversity

Canals and other wetland have significant impact on local ecology and biodiversity (Mitsch 1994). In most of the wetland as well as canals, especially the fertile flood plains have high agricultural value. Paddy and other crops are cultivated here in the dry season. During the wet season, these wetlands merge with the adjacent rivers and become fishing grounds. Agriculture and fishing in these wetlands and canals are very much associated with the economy of local people.

\section{Conclusion}

This study tries to discuss the encroachment processes and its impact as well as the present conditions of the canals. It is evident that the canals are in dismal condition and requires immediate recovery steps. These canals are the vessels of the city and the blockade of them will cause the city to experience severe environmental consequences. To maintain proper drainage system and environmental sustainability, it is imperative to recover the canals from the land grabbers and regularly excavate.

It is true that urbanization in Dhaka city would not be stopped, but these should be based on 
further specific studies and understanding of the hydrological system of the area, not just demand driven unplanned expansion. Special care should be given to the development and alteration of the existing water bodies so that natural hydrological condition can cope to the artificial structural actions.

In 2010, Parliamentary Standing Committee on Ministry of Environment \& Forests (PSCMEF) suggests that, in order to protect Dhaka from frequent internal floods, a total of at least $40 \%$ of the drainage catchment area must be delineated and protected as wetlands and water bodies under the purview of Wetland Conservation Act 2000. Considering the urgency of the matter in the backdrop of rapid filling up of low lands, and to protect the city from frequent flooding and damage of its ecosystem, it is strongly proposed that these $40 \%$ wetlands including the reserved ponds/lakes be declared by the Ministry of Environment and Forest as ecologically critical area (ECA) through official gazette notification without much delay. Of $40 \%$, a minimum of $12 \%$ of the drainage catchment area can be made available as reserved ponds or lakes and developed as water parks and the rest $28 \%$ protected as natural wetlands for the retention of storm water. This strategy can be effective in protecting the canals and wetlands in Dhaka city.

To prevent the waste dumping in the canals, source reduction can be an effective option. Composting of solid wastes can significantly reduce the amount of wastes. While it may take some time to introduce source reduction and separation practice in Dhaka city, implementation of "integrated solid waste management" approach at waste disposal sites would bring significant changes in the present solid waste management scenario. Implementation of ISWM will definitely discourage people to dump waste in the canals.

\section{References}

Ahmed SU (1986) Dacca: A Study in Urban History and Development. The Riverdale Company, Glenn Dale.
Alam M and Rabbani MG (2007) Vulnerabilities and responses to climate change for Dhaka. Environment and Urbanization. 19: 81-97.

BBS (Bangladesh Bureau of Statistics) (2003) Population Census 2001, National Report (Provisional). Ministry of Planning, Government of Bangladesh. Dhaka.

BBS (1977) Bangladesh National Population Census Report 1974. Ministry of Planning, Government of Bangladesh, Dhaka.

BBS (1984) Bangladesh Population Census 1981: Analytical Findings and National Tables. Ministry of Planning. Government of Bangladesh, Dhaka.

BBS (1991) Preliminary Report on Population Census 1991. Ministry of Planning, Government of Bangladesh, Dhaka.

BBS (1997) Bangladesh Population Census 1991, Urban Area Report. Ministry of Planning, Government of Bangladesh, Dhaka.

Brookfield HC et al. (1988) The new great age of clearance and beyond: What sustainable development is possible? University of California Press, Berkeley.

Burkart K et al. (2008) Megacity Dhaka: urban environment, informal settlements and public health. Geographische Rundschau. 4 (1): 5-10.

Center for Urban Studies (CUS) (2006) Slums of Urban Bangladesh: Mapping and Census, 2005. University of Dhaka. Dhaka, Bangladesh.

Chowdhury JU et. al. (2001b) Impact of land use change upon storm water drainage and wetlands in the eastern part of Dhaka city. Integrated Water Flow Model (IWFM), Bangladesh University of Engineering \& Technology (BUET). Dhaka, Bangladesh.

Chowdhury JU et. al. (2001a) Impact of 1998 flood on Dhaka city and performance of flood control works. Integrated Water Flow Model (IWFM), Bangladesh University of Engineering \& Technology (BUET). Dhaka.

D’oyly C (1824) Antiquities of Dacca. J. J. Landseer and Company, London.

Dani AH (1962) Dacca: A Record of Its Changing Fortunes. Ahmed Hasan Dania \& Mrs. S. S. Dani. Dhaka.

Dewan AM and Nishigaki KTM (2006) Flood hazard delineation in greater Dhaka, Bangladesh using an Integrated GIS and remote sensing approach. Geocarto International. 21: 33-38. 
Dewan AM \& Yamaguchi $Y$ (2008) Using remote sensing and GIS detect and monitor land use and land cover change in Dhaka Metropolitan of Bangladesh during 1960-2005. Springer Science B.V.

Flood Action Plan (FAP) 8A (1991) Master Plan Study for Greater Dhaka Protection Projec. Japan International Cooperation Agency. Dhaka.

Islam MN (2009) Rainfall and temperature scenario for Bangladesh. The Open Atmospheric Science Journal. 3: 93-103.

Islam MS et. al. (2010) Changes in Wetlands in Dhaka City: Trends and Physico-environmental Consequences. J. Life Earth Sci. 5: 37-42.

Islam N (1996) Dhaka: from city to mega city. University of Dhaka. Dhaka, Bangladesh.

JICA (1991) Master plan for greater Dhaka protection project (Study in Dhaka metropolitan area). Japan International Cooperation Agency (JICA). Dhaka.

JICA (1992) Master Plan for Greater Dhaka Protection Project, Flood Action Plan, FAP 8A, Main Report and Supporting Reports I and II. Flood Plan Coordination Agency (presently WARPO). Dhaka, Bangladesh.

Kamal ASMM and Midorikawa S (2004) GIS-based geomorphological mapping using remote sensing data and supplementary geoinformation: A case study of the Dhaka city area, Bangladesh. International Journal of Applied Earth Observation and Geoinformation. 6: 111-125.

Khuda ZRMM (2001) Environmental Degradation Challenges of the 21st Century. Environmental Survey and Research Unit. Dhaka. Bangladesh.

Mahmud MS et. al. (2011) Remote Sensing \& GIS Based Spatio-Temporal Change Analysis of Wetland in Dhaka City, Bangladesh. Journal of Water Resource and Protection. 3 (Nov. 2011) 781787 doi:10.4236/jwarp.2011.311088.

Mark, O. et. al. (2001) A mouse GIS study of the drainage in Dhaka city. Surface Water Modeling Center (SWMC). Dhaka, Bangladesh.

Miah MM and Bazlee BL (1968) Some aspects of geomorphology of the Madhupur Tract. Oriental Geographers. 12: 39-48.
Mitsch WJ, Mitsch RH and Turner RE (1994) Wetlands of the Old and New Worlds: Ecology and Management, In Global Wetlands: Old World and New. Elsevier Science B. V. Amsterdam, Netherland

Nakashima S. and Khan MH (1994) A Basic Guide to Understanding the Environmental Impacts of Rural Roads on the Wetlands of Bangladesh. Care International. Bangladesh.

Reza, A. N. M. G. and Alam, M. S. 2002. Wetland transformation in the western part of Dhaka city (1963-2000). Bhugal Patrika (Journal of Geography). 21, 23-40.

Siddiqui, K. et al. 2000. Overcoming the Governance Crisis in Dhaka City. University Press Limited, Dhaka.

Sire LK and Balamurugan G (1991) Urbanization and urban water problems in Southeast Asia a case of unsustainable development. Journal of Environmental Management. 32: 195-209.

Sultana MS, Islam GMT and Islam Z (2009) Pre- and Post urban Wetland Area in Dhaka City, Bangladesh: A Remote Sensing and GIS Analysis. Journal of Water Resource and Protection. 1 (June 2009) 414- 421. doi:10.4236/jwarp.2009.16050.

Taleb MA (2012) Comparative Study of Urban Area Extension and flood Risk in Dhaka City of Bangladesh. Global Journal of Human Social Science Geography \& Environmental Geosciences. 12 (11).

Taylor J (1840) Sketch of the Topography and Statistics of Dacca. Military Orphan Press, Calcutta.

UN-HABITAT. 2008. State of the World's Cities 2008/9Harmonious Cities. UN-HABITAT.

United Nations (2013) World Urbanization Prospect: The 2012 Revision. Department of Economic and Social Affairs, Population Division.

WASA (1991) Dhaka Regional Groundwater and Subsidence Model. Dhaka Water Supply and Sewerage Authority (WASA). Dhaka, Bangladesh. 